\title{
Australian policy review backs huge cuts in research funding
}

[SYDNEY] An attack on research funding in a government-commissioned report on reforming policy on industry has rocked Australia's scientific community. One proposal in particular, to slash government funding for the country's 65 Cooperative Research Centres (CRCs) by 70 per cent from July 1998, is described as “devastation" by the association that represents the centres. John Moore, Minister for Industry, Science and Tourism in the Coalition government, commissioned the report from David Mortimer, chief executive of the transport company TNT, giving Mortimer the brief of reviewing the government's A \$4-billion (US\$3-billion) annual support for business. The one-man review comes at a time when public support for government has been falling sharply, fanned by criticism of the lack of a clear policy for industry.

Mortimer has proposed that government set a clear goal of doubling the rate of economic growth per capita over 10 years, and streamlining assistance schemes for industry into five key programmes, including innovation, competitiveness and sustainable management of resources.

The proposals have been largely welcomed by business groups. Within the government, however, stout resistance is

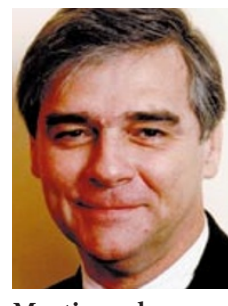

Mortimer: heavy cuts envisaged. emerging from the Treasurer, Peter Costello - a sharp critic of continued subsidies for industry. Moore favours Mortimer's proposals, paving the way for a fierce ideological fight. While attacking last year's unpopular cuts in tax concessions for industrial research and development from 150 to 125 per cent, Mortimer proposes that a further reduction in concession to 100 per cent should be counterbalanced by rebates to companies for expenses on innovation - an effective total of 137 per cent.

Government support for applied research would be reduced and the funding gap filled by industry, a suggestion of which many scientists are critical. "There is no argument or analysis to justify a wholesale dismantling of the public research effort," says Joe Baker, president of the Federation of Australian Scientific and Technological Societies.

The Commonwealth Scientific and Industrial Research Organisation (CSIRO) and the CRC programme would be hit hardest by the recommended cut in support. Mortimer has proposed that CSIRO's external earnings target be increased from 30 to 50 per cent. But the chief executive of CSIRO, Malcolm McIntosh, says Mortimer used "the wrong base" for resetting this target. "His target means 70 per cent of science would have to come out of annual government appropriations," says McIntosh. "This would cripple strategic research and destroy CSIRO."

The CRC scheme is defined as an industry programme in the proposals, and Mortimer has suggested that the government's annual support of A \$146 million be cut to A \$20 million and limited to 'public good' centres. But Mark Sceats, deputy chair of the CRC Association, says the CRCs were shocked, as their scheme was outside Mortimer's brief. Peter McGauran, the Science and Technology Minister, says only that he has "strong views" on the CRC proposals that he plans to convey to the cabinet, of which he is not a member.

Mortimer also proposes that universities — already hit by government cuts - should boost income from business by 50 per cent. Sir Gustav Nossal, president of the Australian Academy of Science, says research cuts are a "by-product" of Mortimer's plans for industry. He has "failed to distinguish basic and strategic research from applications", says Nossal.

Peter Pockley 